\title{
Syndrome of Remitting Seronegative Symmetrical Synovitis with Pitting Edema (RS3PE)
}

\author{
Tekrarlayıcı Seronegatif Pitting Ödemli Simetrik Sinovit Sendromu: Bir Olgu \\ Sunumu
}

\author{
Fatma Paksoy, Turgay Ulaş, Emrah Erkan Mazı, Ayda Batuan Damar, Fatih Borlu \\ şişli Etfal Eğitim ve Araştırma Hastanesi, iç Hastalıkları Kliniği, istanbul, Turkey
}

\begin{abstract}
RS3PE (remitting seronegative, symmetric synovitis with pitting edema) is a benign, seronegative syndrome, with an acute onset of pitting edema on the dorsum of both hands and feet, which affects predominantly peripheral joints such as wrists and ankles symmetrically. A 58-year-old man presented with acute symmetrical polysynovitis of the wrists and ankles associated with pitting edema on the dorsum of the both hands and feet. He responded well to low-dose corticosteroids. There was no evidence of erosion radiologically. The clinical manifestations of the patient were consistent with RS3PE syndrome. Here, we present a case of RS3PE and review the literature.

(Turk J Rheumatol 2010; 25: 88-90)
\end{abstract}

Key words: Pitting edema, seronegative, symmetric arthritis, synovitis

Received: 24.12 .2008

Accepted: 12.01.2009

\section{Özet}

RS3PE (remitting seronegative, symmetric synovitis with pitting edema), akut olarak ortaya çıkan, simetrik ve sıklıkla el ve ayak bilek eklemlerini tutan sinovit, el ve ayak dorsal yüzünde gode bırakan ödem ile seyreden seronegatif, benign karakterli bir sendromdur. 58 yașında erkek hasta, her iki el ve ayakta gode bırakan ödemin bulunması, el ve ayak bileği eklemlerinde hareketleri kısıtlayan polisinovit ile akut bașlangıc göstermesi, düșük doz kortikosteroid tedavisine dramatik yanıt vererek, eklem erozyonu olușturmadan seyretmesi ile RS3PE sendromu tanısı almıștır. Bu çalıșmada RS3PE sendromlu bir olgu sunularak literatür gözden geçirilmiștir.

(Turk J Rheumatol 2010; 25: 88-90)

Anahtar sözcükler: Pitting ödem, seronegatif, simetrik artrit, sinovit

Alındığı Tarih: 24.12.2008

Kabul Tarihi: 12.01.2009

\section{Introduction}

Remitting, seronegative, symmetric synovitis with pitting edema (RS3PE) is a syndrome with an acute onset, benign course characterized by rheumatoid factor seronegativity, edema on the dorsum of the hands and feet, symmetric distal synovitis, and flexor tendinitis on the fingers. It was first defined by McCarty in 1985 (1).

The disease generally influences men above 60 years of age. The male/female ratio is $4 / 1$. Dramatic response to low-dose steroid and no evidence of articular erosion on radiographs are characteristic (1-3). The joints reported frequently as developing stiffness include the metacarpophalangeal (MCP), proximal interphalangeal (PIP), wrist, shoulder, knee, ankle, and elbows (4). Another important characteristic of RS3PE syndrome is its association with neoplastic and rheumatologic diseases $(3,5)$. Here, we present a case with a diagnosis of RS3PE syndrome who applied with symmetric polyarthritis and pitting edema and who showed rapid clinical and laboratory response to steroid treatment.

\section{Case Presentation}

A male patient aged 58 years applied with the complaints of symmetric swelling, pain and stiffness in wrists and ankles occurring suddenly, with pain in hip and shoulder. His morning stiffness lasted more than one hour and he had been unable to get out of the bed without help within the last week due to the pain. There was no significant personal or family history, and he had been using a non-steroidal anti-inflammatory drug (NSAID) for the pain during for last one month.

On the physical examination, cardiovascular, pulmonary, gastrointestinal, and genitourinary system examina- 
tions were found to be normal. There was obvious $(+3)$ pitting edema on dorsum of the hands and pretibial zone bilaterally. Swelling, warmth, limitation of movement, and tenderness were noted at the ankle, wrist, PIP and MCP joints bilaterally. Upper limb motor strength was $3 / 5$ and lower limb motor strength 4/5. Neck movement was limited in each direction and painful. There was no sensitivity in temporal artery palpation and pulses were normal. There was no Raynaud's phenomenon or exanthema. Shoulder movements were limited and painful. Waist movements were painful in each direction. Laboratory examinations revealed the following: hemoglobin 12.7 $\mathrm{mg} / \mathrm{dl}$, hematocrit $39 \%$, leukocyte $5600 / \mathrm{mm}^{3}$, thrombocyte $170,000 / \mathrm{mm}^{3}$, erythrocyte sedimentation rate $56 \mathrm{~mm} / \mathrm{h}$, and C-reactive protein $25.8 \mathrm{mg} / \mathrm{L}$ (normal limits $0-5 \mathrm{mg} / \mathrm{L}$ ). Thyroid, kidney and liver function tests and tumor indicators were found within normal limits. Total protein, albumin and serum electrolyte levels were normal. IgM rheumatoid factor (RF) and HLA-B27 were negative, and antihistone and anti-nucleosome antibodies were found positive in low titer. There were 2-3 leukocytes in urine analysis. No pathology was observed in joints during radiologic examinations. Abdominal ultrasonography, abdominopelvic computerized tomography, echocardiography, electromyography, and all body bone scintigraphy examinations were considered normal.

The patient was given $20 \mathrm{mg} / \mathrm{day}$ prednisolone for 3 days, which was reduced to a $15 \mathrm{mg} /$ day dose on the $4^{\text {th }}$ day. Swelling on the dorsum of the hands and pretibial zone bilaterally recovered noticeably on the $5^{\text {th }}$ day of treatment. The patient was discharged on the $10^{\text {th }}$ day, when his joint movements were relaxed and his pain had reduced sufficiently so as not to limit his daily life. The patient suffered from slight exacerbations during the one year follow-up while being monitored from the outpatient clinic, with $5 \mathrm{mg} /$ day prednisolone treatment, but no functional loss or deformity occurred.

\section{Discussion}

Remitting, seronegative, symmetric synovitis with pitting edema syndrome is defined as seronegative symmetric polysynovitis and arthritis of the distal limbs, primarily the wrist, MCP, PIP and ankle joints with acute onset, together with pitting edema on the dorsum of the hands and feet (1). Olive et al. (6) evaluated 27 cases with RS3PE retrospectively in 1997 and established the following diagnostic criteria for the disease:

- Clear pitting edema on both hands.

- Polyarthritis with acute onset.

- Age above 50 .

- Negative rheumatoid factor (6).

Non-observation of erosive or degenerative change in joints and dramatic response to low-dose corticosteroid are characteristic (2-5). It is thought that pitting edema, which occurs in distal limbs, develops upon local reaction (1). RS3PE diagnosis in the presented case was based on the following: male gender and age of 58 years, symmetric pitting edema and sudden-onset polyarthritis, nonobservation of erosion on radiographs, and dramatic and rapid clinical and laboratory response to low-dose corticosteroid treatment within one week.

Associations with HLA (1), parvovirus B-19 infection (7), malignancy $(4,8,9)$, rheumatologic and autoimmune diseases (10) and increased vascular endothelial growing factor (VEGF) levels (11) have been cited in the etiopathogenesis.

Low-moderate elevation in sedimentation rate has been determined as a laboratory finding in the disease. RF and antinuclear antibodies (ANA) are negative, while HLA-B7, B22 and B27 tissue antigens may be positive in some patients $(2,3)$. Sedimentation rate was moderately increased in our case and RF was negative.

Response of RS3PE to NSAID treatment is not good (1). Russell et al. (5) reported in their series with 13 cases that the patients responded dramatically to $10 \mathrm{mg} / \mathrm{day}$ prednisolone treatment. It was found in different case series that remission was ensured in an average of 6-18 months with low-dose steroid treatment $(3,5,12)$. Lowdegree flexion contractures that developed on wrists and fingers may sometimes be permanent. Recurrence may not occur or may be seen between 18 months and 12 years $(1,2)$.

Despite the clear criteria, differential diagnosis of RS3PE is very difficult. Important differential diagnoses include amyloid arthropathy, psoriatic arthropathy, crystal arthropathy, rheumatic arthritis (RA), late-onset spondyloarthropathies, Reiter syndrome, and mixed connective tissue disease, they cause pitting edema on the hands and feet (12).

Progressive swelling and non-recovery with treatment in amyloid arthropathy, typical skin findings in psoriatic arthritis, and determination of chondrocalcinosis radiologically and crystals in synovial fluid in crystal arthropathy are useful distinctions. Reiter syndrome is differentiated by asymmetric stiffness with conjunctivitis and urethritis and asymmetric pitting edema in lower limbs; late-onset spondyloarthropathies are differentiated by asymmetric pitting edema with sacroiliitis; and mixed connective tissue disease is differentiated by Raynaud's phenomenon and ANA positivity in high titer $(1,3,6,12)$. These were not seen in our case.

Asymmetric pitting edema may be seen in late-onset RA rarely. While having very similar clinical findings and symptoms, it is distinguished from RS3PE with RF positivity and bone erosions (3).

Remitting, seronegative, symmetric synovitis with pitting edema is most frequently confused with polymyalgia rheumatica (PMR) since both are seronegative, are seen in older ages and respond to corticosteroids. Salvarani et al. (13) found pitting edema in $8 \%$ of the cases in their study examining 245 cases with PMR diagnosis. Cantini et al. (2) argued that RS3PE may be a precursor or continuance of PMR since inflammation selects the same ana- 
tomic target in extra-articular synovial structures in magnetic resonance imaging in PMR cases with pitting edema like RS3PE. However, PMR is a disease mostly seen in women, requiring long-term steroid treatment and showing relapse and recurrence more frequently $(2,3,5,10)$. In our case, although pain and limitation of motion in the shoulder and pelvic band were present, dramatic response to corticosteroid treatment in very low doses in a short time supports the diagnosis of RS3PE.

Cases diagnosed as RS3PE are observed to suffer from different rheumatologic diseases in the future, including RA, Sjögren's syndrome, spondyloarthropathy, and PMR $(1,3,13)$.

Association of RS3PE with hematological (myelodysplastic syndrome, leukemia, lymphoma) and solid (gastric, endometrial, pancreatic adenocarcinoma) malignancies has been reported in many studies $(6,8,14,15)$. Although patients with RS3PE respond well to low-dose steroids, response to steroids was not complete in the paraneoplastic RS3PE, and symptoms and findings resolved fully with resection of carcinoma $(4,14,15)$. RS3PE may also be observed before development of a neoplasm. The clinician should remember the paraneoplastic form of RS3PE in such cases with no response to corticosteroid treatment with systemic symptoms (fever, loss of weight, anorexia) $(8,14)$. Our case was also examined in detail for malignancy and none was determined.

In conclusion, although its diagnostic criteria are clear, RS3PE is a syndrome with a benign course, the differential diagnosis of which is very difficult, and it may lead to rheumatologic and neoplastic diseases. Correct recognition of these cases and patient follow-up after diagnosis are important.

\section{Conflict of Interest}

No conflict of interest is declared by authors.

\section{References}

1. McCarty DJ, O'Duffy JD, Pearson L, Hunter JB. Remitting seronegative symmetrical synovitis with pitting edema. RS3PE syndrome. JAMA 1985; 254: 2763-7.

2. Cantini F, Salvarani C, Olivieri I, Benozzi L, Macchioni L, Nicolli $L$, et al. Remitting seronegative symmetrical synovitis with pitting edema (RS3PE) syndrome: a prospective follow up and magnetic resonance imaging study. Ann Rheum Dis 1999; 58: 230-6.

3. Finnel JA, Cuesta IA. Remitting seronegative symmetrical synovitis with pitting edema (RS3PE) syndrome: a review of the literature and a report of three cases. J Foot Ankle Surg 2000; 9: 189-96.

4. Sibilia J, Friess S, Schaeverbeke T, Maloisel F, Bertin P, Goichat $B$, et al. Remitting seronegative symmetrical synovitis with pitting edema (RS3PE): a form of paraneoplastic polyarthritis? J Rheumatol 1999; 26: 115-20.

5. Russell EB, Hunter JB, Pearson L, McCarty DJ. Remitting, seronegative, symmetrical synovitis with pitting edema-13 additional cases. J Rheumatol 1990; 17: 633-9.

6. Olive A, Del Blanco J, Pons $M$, Vaquera $M$, Tenax and the Catalan Group. The clinical spectrum of remitting seronegative symmetrical synovitis with pitting edema. J Rheumatol 1997; 24: 333-6.

7. Perandones $\mathrm{CE}$, Colmegna I, Arana RM. Parvovirus B19: another agent associated with remitting seronegative symmetrical synovitis with pitting edema. J Rheumatol 2005; 32: 389-90.

8. Vinci M, Malaguarnera L, Pistone G. RS3PE and ovarian cancer. Ann Rheum Dis 2001; 60: 429-31.

9. Tunc SE, Arslan C, Ayvacioglu NB, Sahin M, Akkus S, Yorgancigil H. Paraneoplastic remitting seronegative symmetrical synovitis with pitting edema (RS3PE syndrome): a report of two cases and review of the literature. Rheumatol Int 2004; 24: 234-7.

10. Cimmino MA, Silvestri E, Garlaschi G. Remitting seronegative symmetrical synovitis with pitting oedema (RS3PE) as recurrence of aborted PMR. Ann Rheum Dis 2001; 60: 303.

11. Arima $K$, Origuchi T, Tamai $M$, Iwanaga $N$, Izumi $Y$, Huang $M$, et al. RS3PE syndrome presenting as vascular endothelial growth factor associated disorder. Ann Rheum Dis 2005; 64: 1653-5.

12. Doğan ȘK, Tur BS, Tuncer S, Seçkin B. Tekrarlayıcı seronegatif pitting ödemli (RS3PE) simetrik sinovit sendromu: bir olgu sunumu. Rheumatism 2007; 22: 72-5.

13. Salvarani C, Gabriel S, Hunder GG. Distal extremity swelling with pitting edema in polymyalgia rheumatica. Report on 19 cases. Arthritis Rheum 1996; 39: 73-80.

14. Tada $Y$, Sato H, Yoshizawa S, Kimura H, Kitamura M, Kusaba $\mathrm{T}$, et al. Remitting seronegative symmetrical synovitis with pitting edema associated with gastric carcinoma. J Rheumatol 1997; 24: 974-5.

15. Russell EB. Remitting seronegative symmetrical synovitis with pitting edema syndrome: followup for neoplasia. J Rheumatol 2005; 32: 1760-1. 